E-ISSN. 2685-7650

Vol. 2 No. 2 (2020), pp 81-91

DOI: https://doi.org/10.33366/jkn.v2i2.54

\title{
Strategi Komunikasi Pemasaran dalam Pengembangan Pariwisata Kabupaten Blitar Pada Penggunaan Aplikasi Amazing Blitar
}

\author{
Andiwi Meifilina \\ Program Studi Ilmu Komunikasi, Universitas Islam Balitar \\ Email: andiwimeifilina1@yahoo.co.id
}

\begin{abstract}
The purpose of this study is to determine the marketing communication strategy in the development of regional tourism in Blitar using the Amazing Blitar application. This study uses descriptive qualitative research method, with documentative data collection technique. The result showed that the use of STOP SIT marketing communication strategy in marketing communication strategy in the development of tourism in the Blitar in the use of Amazing Blitar application, namely Segmentation, Targeting, Objectives, Positioning, Sequence of Tools, Integrating, Tools. In the marketing communication strategy in the development of tourism in the Blitar area, the use of the Amazing Blitar application continues to be studied to determine the strengths and weaknesses of the Amazing Blitar application, identifying all opportunities and obstacles or threats faced. Marketing promotion or development programs are prepared by considering various aspects and analyzing the target market, namely tourists from both within and outside Blitar. In the STOP SIT marketing communication strategy must be a planning which is an introduction to the problem, namely an analysis of the external and internal environment which produces several main problems or weaknesses, strengths, threats and opportunities. So that in the STOP SIT analysis, it is better if you also know the problem or obstacle or strength that the company has, both in terms of human resource capabilities, technology applications, facilities, capitals, and networks.
\end{abstract}

\section{Keywords: Marketing communication strategy, regional tourism, Amazing Blitar application}

\begin{abstract}
Abstrak: Tujuan dari penelitian ini adalah untuk mengetahui strategi komunikasi pemasaran dalam pengembangan pariwisata daerah Kabupaten Blitar pada penggunaan aplikasi Amazing Blitar. Penelitian ini menggunakan metode penelitian kualitatif deskriptif, dengan teknik pengumpulan data secara dokumentatif. Hasil penelitian menunjukkan bahwa Adanya penggunaan strategi komunikasi pemasaran STOP SIT pada strategi komunikasi pemasaran dalam pengembangan pariwisata daerah Kabupaten Blitar pada penggunaan aplikasi Amazing Blitar yaitu Segmentation, Targeting, Objectives, Positioning, Sequence of Tools, Integrating, Tools. Pada strategi komunikasi pemasaran dalam pengembangan pariwisata daerah Kabupaten Blitar dalam penggunaan aplikasi Amazing Blitar terus dilakukan kajian untuk mengetahui kekuatan dan kelemahan aplikasi Amazing Blitar, mengidentifikasi semua peluang dan hambatan atau ancaman yang dihadapi. Program promosi atau pengembangan pemasaran dipersiapkan dengan mempertimbangkan berbagai aspek, dan menganalisa pasar yang di tuju yaitu para wisatawan baik dari dalam Kabupaten Blitar maupun luar Kabupaten Blitar. Di dalam strategi komunikasi pemasaran pemasaran STOP SIT harus ada perencanaan yang merupakan pengenalan masalah yaitu analisis lingkungan eksternal dan internal yang menghasilkan beberapa pokok permasalahan atau kelemahan, kekuatan, ancaman dan peluang sehingga dalam analisis STOP SIT sebaiknya juga mengetahui permasalahan atau hambatan maupun kekuatan yang dimiliki oleh perusahaan, baik dalam hal kemampuan sumber daya manusia, aplikasi teknologi, fasilitas, modal, maupun jaringan.
\end{abstract}

Kata Kunci: Strategi komunikasi pemasaran, pariwisata daerah, aplikasi Amazing Blitar

\section{Pendahuluan}

Pariwisata memiliki banyak macam, dan oleh sebab itu pariwisata memiliki banyak komponen. Kompone-komponen dalam pariwisata meliputi jasa pelayanan pariwisata, sosial, ekonomi, budaya, politik, keamanan, dan lingkungan (Sembiring, 2016). Kabupaten Blitar merupakan sebuah kabupaten yang memiliki potensi wisata yang sangat bagus. Selama beberapa 


\section{Jurnal Komunikasi Nusantara}

E-ISSN. 2685-7650

Vol. 2 No. 2 (2020), pp 81-91

DOI: https://doi.org/10.33366/jkn.v2i2.54

tahun belakangan pengembangan pariwisata seperti wisata alam, wisata buatan dan wisata budaya terus dilakukan di Kabupaten Blitar. Beberapa wisata alam yang berada di Kabupaten Blitar adalah wisata Pantai Serang, Pantai Tambak dan lain-lain serta beberapa objek wisata buatan seperti Blitar Park, Kampung Cokelat dan juga wisata sejarah seperti candi Penataran, candi Simping yang memiliki cerita sejarah yang cukup dikenal. Untuk mendukung kemajuan pariwisata di Kabupaten Blitar maka di Dinas Pariwisata Pemuda dan Olah Raga Kabupaten Blitar melakukan strategi promosi pariwisata dengan membuat slogan "Amazing Blitar". Program strategi promosi pariwisata ini ditujukan sebagai upaya untuk mempercepat pembangunan dan persiapan sektor pariwisata.

Dunia industri pariwisata di Kabupaten Blitar dapat dikatakan sebagai lini terdepan setelah sektor pertanian dan peternakan dalam upaya peningkatan pendapatan masyarakat dan daerah. Selain kaya dengan panorama alam serta seni dan budayanya, adat-sitiadat dan tradisi di masyarakat serta faktor-faktor pendukung lainnya mendorong pemerintah Kabupaten Blitar lebih serius membenahi sektor pariwisata. Dalam hal ini pemerintah melakukannya dengan membuat aplikasi Amazing Blitar. Melalui aplikasi ini pemerintah melakukan strategi komunikasi pemasaran agar sektor pariwisata di Blitar semakin banyak dikunjungi wisatawan.

Secara umum, strategi merupakan suatu garis besar haluan dalam bertindak untuk mencapai sasaran yang telah ditentukan (Asrori, 2016). Dengan demikian, strategi komunikasi pemasaran berhubungan dengan membuat perencanaan program komunikasi yang efektif bagi suatu perusahaan atau produk-produk tertentu. Perencanaan komunikasi berhubungan dengan cara penyebaranluasan pesan yang tepat dari komunikator kepada masyarakat secara benar dan tepat sasaran (Wijaya, 2015).

Apapun bentuk kegiatan komunikasi yang dilakukan suatu perusahaan atau organisasi akan memperoleh hasil yang kurang efektif jika tidak dibarengi dengan perencanaan komunikasi pemasaran yang baik. Hal ini terjadi karena pada dasarnya komunikasi pemasaran adalah hubungan yang terjadi secara terus menerus antara produsen dan konsumen atau antara perusahaan dengan masyarakat (Delozier, 1976; Alifahmi, 2005). Oleh sebab itu, dalam proses ini harus ada komunikasi dua arah dan persuasi yang signifikan agar komunikasi pemasaran yang dilakukan terealisasi secara efektif dan efisien (Nickels, 1984). Adapun yang dimaksud dengan proses berkelanjutan dalam strategi komunikasi pemasaran adalah dimulainya kegiatan mulai dari tahap perencanaan produk, distribusi, hingga kegiatan promosi dan penggunaan oleh konsumen (Lukitaningsih, 2013).

Tidak berbeda dengan apa yang sudah dijelaskan sebelumnya, kegiatan komunikasi pemasaran berkaitan erat dengan usaha untuk menginformasikan, memperkenalkan, membujuk, menciptakan interaksi antara dua entitas atau lembaga, sehingga terjadi pertukaran antara perusahaan atau suatu lembaga dengan mitra atau konsumen (Afrilia, 2018; Kusniadji, 2016; Chrismardani, 2014; Armstrong \& Kotler, 2004). Proses ini tidak lain difungsikan untuk mempengaruhi target sasaran agar meningkatkan kunjungan dan membeli produk dan jasa yang ditawarkan oleh suatu lembaga perusahaan (Sarastuti, 2017; Aprilya, 2017).

\section{Metode Penelitian}




\section{Jurnal Komunikasi Nusantara}

\section{E-ISSN. 2685-7650}

Vol. 2 No. 2 (2020), pp 81-91

DOI: https://doi.org/10.33366/jkn.v2i2.54

Penelitian ini menggunakan penelitian kualitatif deskriptif. Bodgan dan Taylor mendefinisikan pendekatan secara kualitatif sebagai prosedur penelitian yang menghasilkan data deskriptif berupa kata-kata tertulis atau lisan dari orang-orang atau perilaku yang diamati (Moleong, 2014). Oleh sebab itu, dalam konteks ini, seorang peneliti sangat berperan penting dalam proses penelitian ini. Kemudian, pengumpulan data dilakukan dengan menggunakan teknik dokumentasi, yaitu aplikasi Amazing Blitar. Data kemudian dianalisa tiga alur secara bersamaan, yaitu reduksi data, penyajian data, penarikan kesimpulan/verifikasi (Miles \& Huberman, 1992).

\section{Hasil dan Pembahasan}

Amazing Blitar adalah aplikasi informasi tempat-tempat penting (Point of Interest) untuk Kabupaten Blitar. Aplikasi ini bisa membantu wisatawan lokal atau dari luar Kabupaten untuk mencari tempat untuk berwisata online atau offline. Pemerintah Kabupaten Blitar merilis aplikasi Amazing Blitar untuk mempermudah wisatawan mengeksplor setiap lekuk keindahan dan kebudayaan Blitar. Perkembangan teknologi digital makin mempermudah setiap wisatawan mendapatkan pengalaman liburan lebih menyenangkan. Kemajuan teknologi ini yang kemudian dimanfaatkan Pemerintah Kabupaten Blitar untuk menciptakan aplikasi guide untuk wisatawan. Seperti yang sudah diketahui, Kabupaten Blitar memiliki beragam destinasi wisata sebvanyak 90 destinasi wisata yang bisa dikunjungi.

Untuk bisa mengeksplor ke tempat-tempat tersebut sangat dibutuhkan seorang guide lokal yang handal dan tahu medan tempat wisata.Agar perjalanan para wisatawan keliling tempat wisata di Kabupaten Blitar lebih mudah, maka Pemerintah Kabupaten Blitar meluncurkan aplikasi bernama Amazing Blitar. Melalui aplikasi ini, para wisatawan bisa mengakses informasi destinasi wisata lebih mudah.Ada lebih dari 10 kategori destinasi wisata mulai dari wisata alam, candi, wisata pantai, wisata sejarah, wisata kuliner, hingga wisata religi. Masing-masing kategori terdapat puluhan destinasi yang bisa dikunjungi. Misalnya, saat wisatawan masuk ke dalam kategori Pantai, maka akan muncul beragam pilihan pantai seperti Pantai Pasur, Pantai Gayasan, Pantai Pudak, Pantai Banteng Mati, dan banyak lainnya. Pada saat wisatawan meng-klik nama destinasi yang dituju, akan muncul deskripsi singkat tentang destinasi tujuan tersebut dan supaya tampilan makin menarik, maka aplikasi Amazing Blitar ini pun dilengkapi dengan foto-foto destinasi wisata yang cantik.

Menariknya, dalam aplikasi Amazing Blitar ini setiap destinasi wisata tak hanya sajikan deskripsi dan lokasi saja, tapi juga dilengkapi dengan teknologi Global Positioning System (GPS), Augmented Reality (AR) dan Google Maps. Wisatawan tidak perlu bingung mencari keberadaan destinasi yang ingin di tuju. Aplikasi Amazing Blitar juga memungkinkan penggunanya untuk memberikan review dan mengunggah foto perjalanan yang sudah dilakukan pada aplikasi Amazing Blitar. Aplikasi amazing Blitar ini bisa dibilang sangat lengkap karena tidak hanya sajikan rekomendasi tempat wisata saja, tapi juga tempat menginap, transportasi, hingga kantor pemerintahan lengkap dengan alamat dan reviewnya. Jadi, jika wisatawan sedang merencanakan liburan ke Blitar, rasanya aplikasi Amazing Blitar ini sudah sangat cukup menjadi guide perjalanan wisatawan. Saat ini, aplikasi Amazing Blitar baru tersedia untuk para pengguna Android saja. Wisatawan bisa mengunduhnya dari Google Playstore dan setelah itu wisatawan 


\section{Jurnal Komunikasi Nusantara}

\section{E-ISSN. 2685-7650}

Vol. 2 No. 2 (2020), pp 81-91

DOI: https://doi.org/10.33366/jkn.v2i2.54

akan diminta untuk melakukan registrasi dengan memasukan id facebook atau pun akun google. Aplikasi Amazing Blitar ini bisa diunduh secara gratis atau cuma-cuma dan aplikasi wisata ini tak membutuhkan banyak kuota hanya sekitar 5 MB.

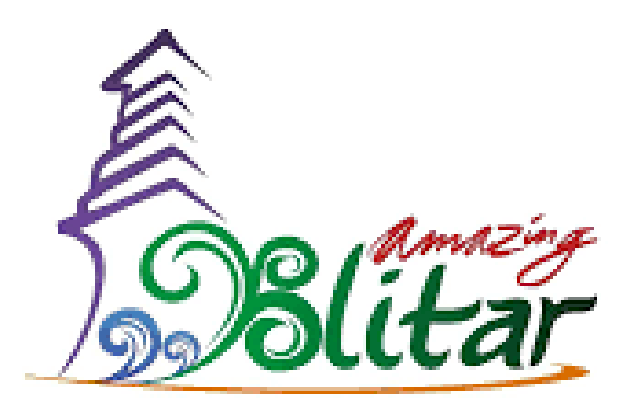

Gambar 1: logo dari aplikasi Amazing Blitar

Beberapa tempat wisata yang berada dalam aplikasi Amazing Blitar:

a. Kampung Cokelat

Wisata Edukasi Kampung Coklat di Blitar menarik banyak pengunjung. Tidak hanya warga Blitar saja yang datang ke tempat ini, karena tidak sedikit warga luar kota yang datang ke tempat ini bersama keluarganya. Wisata kampung coklat Blitar memang bisa dibilang menarik, karena memanfaatkan gudang dan kebun coklat sebagai tempat wisata untuk keluarga yang belum ada di sekitar Blitar. Kampung coklat merupakan salah satu referensi wisata di Blitar yang baru-baru ini populer. Begitu memasuki area wisata kampung coklat, anda akan mencium semerbak aroma coklat di sekitar area. Anda akan mendapati area penjemuran coklat di depan tiket masuk. Untuk masuk ke area ini anda diharuskan membayar retribusi untuk pengembangan area wisata sebesar 5 ribu rupiah per orang. Loket kampung coklat, loket kampung coklat. Setelah membeli tiket seharga 5 ribu rupiah anda bisa langsung masuk dan langsung mendapatkan suguhan pemandangan kebun coklat yang sudah ditata sedemikian rupa dan terdapat beberapa outlet-outlet yang menyediakan aneka olahan coklat seperti es coklat, ice cream coklat, hingga mi coklat. Selain itu juga ada pilihan menu makanan yang lain. Suasana kampung coklat suasana kampung coklat. Gambar di atas diambil ketika hari biasa, sehingga pengunjung tidak terlalu banyak. Apabila wisatawan datang saat musim liburan, wisata kampung coklat ini sangat ramai. Berikut foto ketika liburan tahun baru kemarin tim dari mblitar.net mencoba berkunjung ke kampung coklat. Liburan di kampung coklat liburan di kampung cokelat.

Ada banyak fasilitas yang sudah disediakan oleh pengelola kampung coklat, selain area kuliner di akhir pekan terdapat panggun hiburan yang akan menemani liburan anda bersama keluarga sehingga lebih semarak. Selain keluarga, tidak sedikit rombongan kawula muda yang datang untuk menikmati suasana kebun coklat yang sulit di jumpai.Outlet minuman coklat outlet minuman coklat. Selain fasilitas outlet yang menjual minuman berbahan dasar coklat, anda juga bisa menikmati refleksi ikan pada sebuah kolam yang 


\section{Jurnal Komunikasi Nusantara}

E-ISSN. 2685-7650

Vol. 2 No. 2 (2020), pp 81-91

DOI: https://doi.org/10.33366/jkn.v2i2.54

disediakan. Sayangnya panggung hiburan hanya ada saat weekend saja. Sehingga hari-hari biasa tidak ada apa apa di panggung hiburan ini. Fasilitas mushola juga sudah disediakan oleh pengelola untuk yang ingin melakukan ibadah sholat ketika berada di kampung coklat. Selain menikmati aneka olahan coklat, anda juga bisa mengikuti cooking class dan melihat kebun-kebun pembibitan cokelat. Pembibitan coklat tidak setiap hari ada, ada musimnya, sehingga apabila beruntung anda bisa melihat bibit cokelat yang masih kecil-kecil. Kebun bibit cokelat di kampung coklat Blitar ini merupakan salah satu tempat favorit pengunjung untuk berfoto bibit pohon coklat. Sebelum pulang wisatawan bisa mampir ke gerai yang menjual aneka olahan cokelat seperti brownies cokelat, permen cokelat hingga jual bubuk cokelat yang digunakan pada minuman dan ice cream. Bubuk cokelat ini sama dengan yang digunakan pada outlet-outlet mini yang ada dalam area wisata kebun cokelat. Apabila konsumen berada di luar kota dan tidak sempat membeli berbagai macam oleh-oleh Blitar di kampung cokelat, mereka bisa membeli melalui toko online.

b. Pantai Peh Pulo

Bila para wiatawan menginginkan pemandangan pantai yang berbeda, tidak ada salahnya bila kita mengunjungi Pantai Peh Pulo. Berbeda dengan pantai-pantai yang sudah memiliki nama di Kabupaten Blitar seperti tambak, serang dan jolosutru, Pantai Peh Pulo bisa memberikan nuansa berbeda. Terletak di ujung tenggara wilayah Kecamatan Panggungrejo, selain wisatawan harus melalui kawasan perbukitan dan hutan yang ada di wilayah Kecamatan Panggungrejo, ruas jalan menuju ke lokasi pantai sebagian masih berupa jalan makadam yang licin. Wisatawan bisa langsung menuju tepi pantai dan bermain air. Ombaknya tidak begitu besar, sebab agak ke tengah dari tepi pantai, berjajar pulau-pulau kecil yang seolah membentengi pantai dari gempuran ombak.

c. Candi Penataran/ Candi Palah

Candi Panataran adalah sebuah candi berlatar belakang Hindu (Siwaitis) yang terletak Desa Penataran Kecamatan Nglegok, tepatnya di lereng barat daya Gunung Kelud, di sebelah utara Blitar jarak tempuh dari pusat kota kurang lebih $12 \mathrm{Km}$. Komplek Candi ini merupakan yang terbesar di Jawa Timur. Candi ini di bangun dari Kerajaan Kediri dan dipergunakan sampai dengan Kerajaan Majapahit, Seperti pada umumnya relief candi di Jawa Timur yang dipahat berdasarkan analogi romantika hidup tokoh yang didharmakan di tempat tersebut, relief Ramayana dengan tokoh Rama dan Shinta, dan relief Krisnayana dengan tokoh Krisna dan Rukmini, yang dipahatkan pada dinding candi Penataran dapat dikatakan mirip dengan kisah Ken Arok dan Ken Dedes.Keberadaan Wisata Candi Penataran sangat membantu mengangkat perekonomian masyarakat di Sekitar Candi, banyaknya kios-kios penjual sangat memudahkan wisatawan untuk mencari oleh-oleh, selain itu untuk lebih memikat Wisatawan Pemerintah Kabupaten Blitar juga membangun Fasilitas Wisata lain yaitu pemandian atau kolam renang yang jaraknya tiak terlalu jauh dari Kawasan Candi Penataran.

d. Sirahkencong

Sirahkencong merupakan suatu area perkebunan yang terletak di Desa Ngadirenggo, Kecamatan Wlingi, Kabupaten Blitar yang termasuk dalam areal perkebunan teh Persero Perkebunan Bantaran PTPN XII. Lokasinya kurang lebih $36 \mathrm{~km}$ ke timur dari pusat Kabupaten Blitar. Perkebunan ini berada di lereng barat daya Gunung Kawi pada ketinggian 


\section{Jurnal Komunikasi Nusantara}

E-ISSN. 2685-7650

Vol. 2 No. 2 (2020), pp 81-91

DOI: https://doi.org/10.33366/jkn.v2i2.54

kurang lebih $100 \mathrm{M}$ dari permukaan laut. Untuk mencapai tempat ini bisa dijangkau dengan 2 jalur, jalur pertama melalui Kecamatan Wlingi dan jalur kedua melalu sisi timur yaitu melalui Desa Pijiombo. Pemandangan di perkebunan teh ini sangatlah mencengangkan dan menakjubkan bagi wisatawan yang mengunjunginya, hamparan luas perkebunan teh yang berwarna hijau dan berbukit membuat para wisatawan enggan untuk cepat-cepat meninggalkan tempat ini. Selain itu air sungai yang mengalir di perkebunan ini sangatlah bening dan dingin sehingga wisatawan yang berminat mengunjungi tempat ini akan merasakan kesejukan, kedamaian dan keindahan tanpa bosan. Perkebunan Bantaran PTPN XII juga menjajakan beberapa hasil produk unggulan tehnya dengan merk "Ken Tea" sehingga wisatawan dapat membawa oleh-oleh untuk dibawa pulang.

e. Candi Sawentar

Candi Sawentar terletak di Desa Sawentar, Kecamatan Kanigoro Kabupaten Blitar Jawa Timur. Di dalam Kitab Negarakertagama, Candi Sawentar disebut juga Lwa Wentar. Bangunan candi ini dahulu merupakan sebuah kompleks percandian, karena di sekitarnya masih ditemukan sejumlah pondasi yang terbuat dari bata. Candi Sawentar diduga dibangun pada awal berdirinya Kerajaan Majapahit. Candi yang terbuat dari batu andesit ini berukuran panjang 9,53 m, lebar 6,86 $\mathrm{m}$ dan tingginya $10,65 \mathrm{~m}$. Pintu masuk menuju bilik berada di sebelah barat, dengan ornamen makara pada pipi tangga, sedangkan relung-relungnya terdapat pada setiap dinding luar tubuh candi. Di dalam ruangan bilik ditemukan akas arca dengan pahatan burung garuda, yang dikenal sebagai kendaraan Dewa Wisnu. Berdasarkan hal ini dapat diketahui bahwa Candi Sawentar merupakan bangunan suci yang berlatar belakang agama Hindu.

f. Pantai Serang

Pantai Serang merupakan pantai yang terletak di pesisir Pantai Selatan atau di Samudra Hindia, tepatnya berada di Desa Serang, Kecamatan Panggungrejo Kabupaten Blitar kurang lebih $45 \mathrm{Km}$ arah barat daya Kota Blitar dan jarak tempuhnya kurang lebih 1,5 jam. Pantai ini memiliki hamparan pasir yang putih dan landai serta bibir pantai yang cukup panjang dengan ombak yang tidak terlalu tinggi sehingga memudahkan wisatawan untuk bermain air laut. Pantai serang juga terkenal dengan ritual tradisionalnya yaitu Larung Sesaji yang dilakukan setiap tanggal 1 Suro. Untuk memberikan kesan nyaman sebagai obyek wisata di bibir pantai serang juga di bangun beberapa Gazebo sebagai tempat peristirahatan. Selain itu wisatawan juga bisa menikmati keindahan pantai di sebelah barat dan timur pantai serang yang bisa ditempuh dengan berjalan kaki.

g. Wisata Rambut Monte

Wisata Rambut Monte terletak di Desa Krisik Kecamatan Gandusari kurang lebih 30 km dari Kota Blitar. Candi yang terdapat di lokasi Rambut Monte ini merupakan tempat pemujaan bagi penganut agama Hindu pada jaman Kerajaan Majapahit. Wisata Rambut Monte justru identik dengan telaga yang jernih dan airnya yang hijau yang dihuni oleh ikan, yang oleh warga sekitar di sebut dengan Ikan Dewa. Dalam perjalanan menuju wisata ini wisatawan dimanjakan dengan keindahan sepanjang jalan, hamparan sawar warga setempat dan pemandangan yang hijau dari perkebunan teh wisata Rambut Monte bisa merupakan wisata alam yang terdapat sebuah telaga, candi, petilasan atau tempat untuk bermeditasi 


\section{Jurnal Komunikasi Nusantara}

E-ISSN. 2685-7650

Vol. 2 No. 2 (2020), pp 81-91

DOI: https://doi.org/10.33366/jkn.v2i2.54

karena pengujung bisa menemui sumber mata air pegunungan yang bersih. Untuk memberi kesan lebih dan kenyaman bagi pengunjung pihak pengelola telaga disediakan sebuah gazebo untuk beristirahat dan menikmati keindahan alam di sekitar telaga. Keindahan lokasi Rambut Monte ini kian bertambah dengan pantulan warna air dalam danau yang jernih kehijauan. Pengunjung tidak diperbolehkan untuk berenang di area telaga yang berisi ikan Dewa, tetapi terdapat kolam tersendiri untuk pengunjung berenang menikmati hijaunya alam di Rambut Monte.

h. Candi Plumbangan

Selain candi Penataran, Kabupaten Blitar juga memiliki bebrapa Candi yang bisa dijadikan sebagai Obyek Wisata salah satunya Candi Plumbangan yang terletak di Desa Plumbangan, Kecamatan Doko, Kabupaten Blitar, Jawa Timur, arah timur dari pusat Kota Blitar. Jika ditinjau dari bentuknya, bangunan bersejarah yang disebut sebagai Candi Plumbangan ini sebenarnya bukanlah sebuah candi. Bangunan ini lebih tepat disebut sebagai gapura gaya paduraksa, yaitu gapura dengan atap menyatu. Dirunut dari fungsinya, gapura paduraksa dapat berfungsi sebagai candi ruwatan serta dapat juga sebagai batas wilayah atau komplek bangunan tertentu.Selain bangunan utama berupa gapura paduraksa, di sekeliling Candi Plumbangan juga terdapat prasasti dan sekumpulan artefak lain seperti yoni, arca, dan jaladwara (unsur bangunan yang berfungsi untuk mengalirkan air).

i. Pantai Tambakrejo

Pantai Tambakrejo merupakan pantai yang banyak dikunjungi di Kabupaten Blitar, dengan pemandangan yang indah, pantai yang cukup bersih, air laut yang biru dan pasir putih yang terbentang menjadi sebuah teluk dengan panjang sekitar $10 \mathrm{Km}$. Ombak pantai Tambakrejo pun tidak terlalu besar, sehingga aman untuk bermain-main atau bahkan mandi di pantainya khususnya pada saat menjelang sore di mana air pantai sudah mulai surut.Pantai Tambakrejo terletak di Desa Tambakrejo Kecamatan Wonotirto, kurang lebih 30km ke arah selatan dari kota Blitar dan bisa ditempuh dengan waktu kurang lebih 1 jam. Di kawasan bibir pantai Tambakrejo juga terdapat kampung nelayan dengan perahu-perahu nelayan, mencari ikan merupakan sumber mata pencarian warga di sekitar pantai Tambakrejo. Di kawasan ini juga terdapat tempat pelelangan ikin dan pasar ikan dimana para wisatawan dapat membeli ikan-ikan segar hasil tangkapan para nelayan. Selain keunikan dan keindahan pantainya Pantai Tambakrejo juga terkenal dengan budaya larung sesaji yang dilakukan setiap tahun di bulan Oktober, pada acara ini banyak sekali wisatawan lokal maupun internasional akan berdatangan untuk menyaksikan ritual tradisional ini.

j. Gua Embultuk

Gua Embultuk merupakan sebuah gua alam yang didalamnya penuh dengan stalagmit dan stalaktit. Gua Embultuk terletak di Desa Tumpakkepuh Kecamatan Bakung Kabupaten Blitar arah selatan kota Blitar dengan jarak sekitar $40 \mathrm{~km}$ dan bisa ditempuh dengan waktu kurang lebih 1 jam. Panjang gua ini sekitar 1500 meter sedang luas dan tingginya sekitar 3 meter. Sepanjang kurang lebih 1,5 km, pesona stalagmit akan membuat anda merasa betah dengan suasana yang mengesankan, suara gemericik air bawah tanah menambah kesan alami. Untuk menyusuri gua tersebut Pengunjung harus memakai lampu petromak dan pakaian ganti karena gelapnya Gua dan Permukaan Air yang cukup tinggi. Gua Embultuk merupakan 


\section{Jurnal Komunikasi Nusantara}

\section{E-ISSN. 2685-7650}

Vol. 2 No. 2 (2020), pp 81-91

DOI: https://doi.org/10.33366/jkn.v2i2.54

satu-satunya gua di Blitar yang menyajikan keunikan stalagmitnya pada para pengunjung. Wisata gua ini selalu ramai dikunjungi oleh banyak turis, terutama pada liburan sekolah, mengingat potensi wisatanya yang cukup tinggi pemerintah Kabupaten Blitar telah memperbaiki jalan menuju Gua tersebut sehingga untuk mencapai Gua tersebut bisa ditempuh dengan kendaraan roda 4.

Komunikasi pemasaran dengan strategi STOP-SIT lebih banyak digunakan oleh pelaku pasar dalam upaya mengetahui pemetaan positioning pemasaran untuk mendapat penafsiran bagaimana strategi yang telah dijalankan, apakah sudah baik atau malah sebaliknya, semakin buruk. Semua itu akan dikaitkan dengan misi dan tujuan kegiatan perusahaan. Pada perkembangan saat ini, analisis STOP-SIT lebih banyak dikembangkan dalam pengukuran strategi marketing public relations yang dilakukan oleh suatu organisasi atau perusahaan. Hal ini disebabkan ada faktor keluwesan fleksibilitas dalam pisau analisis STOP-SIT, yang terpenting dalam analisis STOP-SIT adalah adanya unsur utama, yaitu positioning (posisi) atau merk yang akan menempel dibenak khalayak.Apakah strategi dan taktik promosi sudah sesuai dengan situasi, kondisi dan harapan yang diinginkan oleh pelanggan atau klien perusahaan,demikianlah dasar dari pemikiran analisis ini. Dalam analisis dan perencanaan STOP-SIT itu sendiri, unsur yang paling utama dan menjadi inti kemungkinan berhasil strategi dan taktik pemasaran (promosi) adalah STOP. Banyak yang beranggapan unsur SIT hanya bersifat tambahan saja.Oleh sebab itu, syarat mutlak keberhasilan suatu strategi setidaknya dalam uapaya memahami strategi komunikasi perusahaan adalah unsure STOPnya saja.

Strategi komunikasi pemasaran yang biasa disebut sebagai promosi, dahulu nyaris dinyatakan tidak terukur, maka saat ini setelah ada analisis STOP-SIT, pendapat miring tersebut terbantahkan. Dahulu strategi promosi dalam marketing public relations hanyalah akan menghabiskan dana saja karena lebih mendekati sifatnya cenderung seni, abstrak dan tidak ada hasilnya. Memang banyak sekali evaluasi system terhadap strategi promosi public relations, tetapi sangat sedikit yang berani menarik dalam situasi pemasaran dan bisnis perusahaan. Dalam analisis STOP-SIT, penelitian ini akan lebih banyak berbicara kepada kegunaan dan anggaran dari pihak manajemen dalam promosi. Analisa dan pengukuran terhadap STOP-SIT saat ini sering ditafsirkan khalayak dengan strategi marketing public relations (kehumasan pemasaran). Padahal, pada kenyataannya tidak, karena Hermawan Kertajaya, sebagai ahli pemasaran (marketing) menyebut analisis ini dalam versi pemasaran (marketing) dalam konsep STP (Segmentation, Targeting, Positioning). Awalnya memang analisis STOP-SIT hanya muncul dalam empat dimensi analisis besar, yakni STOP. Namun, dalam perkembangan selanjutnya, kajian-kajian analisis ini meluas menjadi STOP-SIT dengan penambahan Scquence of Tools, Integrating dan Tools. Kunci keberhasilan strategi komunikasi pemasaran adalah dari bagaimana penyusun pesan tersebut agar dengan mudah dikenali oleh khalayak. Penyusunan taktik, strategi dan pesan itu sendiri harus berjalan seimbang sesuai dengan di dalam STOP-SIT. Istilah STOPSIT adalah akronim dengan penjabaran sedemikian. Penentuan strategi yang cocok akan sangat tergantung pada kendaraan misi dan visi yang ada. Bagaimanapun juga unsur ini adalah syarat mutlak keberadaan suatu strategi komunikasi pemasaran, dalam penyusunan strategi ini sangat ditentukan aspek-aspek yang ada.

\section{S - Segmentation}




\section{Jurnal Komunikasi Nusantara}

E-ISSN. 2685-7650

Vol. 2 No. 2 (2020), pp 81-91

DOI: https://doi.org/10.33366/jkn.v2i2.54

Segmentation adalah tahapan bagaimana seharusnya mengategorisasikan pasar yang hendak dituju dalam strategi pemasaran yang ada, maka akan dapat dengan mudah pemasaran dan penjualan produk dilakukan. Segmentasi pasar di sini adalah seluruh wisatawan yang berkunjung tempat wisata di Kabupaten Blitar baik yang datang dari Kabupaten Blitar ataupun di luar Kabupaten Blitar dari berbagai usia dan berbagai kalangan.

\section{T - Targeting}

Targeting dalam analisis ini adalah menentukan siapa sasaran yang hendak dituju. Biasanya proses targeting ini lebih ditunjukkan kepada pemiliharaan DMU (Decision Making Unit) atau dalam komposisi khalayak adalah opinion leader. Targeting ini akan memiliki kemampuan menyebarkan pesan informasi yang sudah diberikan oleh korporat atau perusahaan kepada khalayak. Dalam hal ini dengan pengunaan aplikasi Amazing Blitar maka target sasaran sudah sangat jelas yaitu para wisatawan. Para wisatawan akan dapat mengakses informasi melalui aplikasi Amazing Blitar yang berisikan seluruh tempat wisata yang ada di Kabupaten Blitar.

\section{O-Objectives}

Objectives gunanya adalah untuk memahami apakah strategi yang dilakukan dalam komunikasi pemasaran sudah mempunyai tujuan sesuai dengan kondisi lingkungan. Tujuan dalam transfer pesan komunikasi ini bervariasi dan tidak semua pesan spontan, langsung mengalami perubahan. Apakah cukup mengenal dan tahu hingga muncul rasa empati dan ketertarikan yang lebih. Obyektif seharusnya mampu membuat penyelesaian pada kerelaan khalayak tersegmentasi untuk melakukan seperti yang diinginkan. Diasumsikan bahwa pesan dari produsen sampai ke khalayak dan mereka akan melakukan seperti apa yang dipesankan melalui media promosi. Dalam strategi objectives ini pengunaan aplikasi Amazing Blitar sangat objektif karena sasarannya adalah para wisatawan yang berkunjung di tempat pariwisata Kabupaten Blitar. Objektif dengan pemberian informaisi kepadapara wisatawan dengan sesuai kebenaran informasi yang ada di lokasi wisata.

4. P - Positioning

Positioning dan kedudukannya adalah sebagaimana posisi komunikator dan komunikan dalam hubungan-hubungan yang ada serta bagaimana komunikator dipersepsikan dan apa yang diinginkan, hal ini memerlukan strategi yang jitu dan tepat. Perubahan positioning ini tidak serta merta terjadi begitu saja, melainkan memerlukan waktu yang panjang dan cukup lama. Peran positioning sekarang sangat penting apalagi adanya ledakan teknologi media massa. Dalam hal ini, perubahan dalam positioning positif, negatif dan netral memerlukan tenaga, waktu dan usaha yang tidak kecil. Pendekatan mendasar atau positioning bukanlah dengan menciptakan sesuatu yang baru atau berbeda tetapi dengan menggunakan apa yang telah ada di dalam pikiran kita dan mengikat kembali hubungan yang sudah ada.

Positioning adalah janji yang ditawarkan ke pelanggan. Positioning akan kredibel dimata pelanggan jika di back up oleh diferensiasi yang kokoh, unik dan tidak mudah dijiplak oleh pesaing. Kalau positioning dan diferensiasinya cocok, tentunya merk atau brand yang kuat sudah menanti dihadapan. Dalam penggunaan aplikasi Amazing Blitar untuk penawaran tempat wisata sesuai dengan informasi yang disampaiakan pada media massa bahwa tempat wisata di Blitar sangat bagus melalui foto atau gambar yang terdapat di aplikasi Amazing Blitar tersebut. 


\section{Jurnal Komunikasi Nusantara}

E-ISSN. 2685-7650

Vol. 2 No. 2 (2020), pp 81-91

DOI: https://doi.org/10.33366/jkn.v2i2.54

\section{S - Sequence of Tools}

"Sequence of Tools" dalam hal ini adalah taktik yang digunakan dihubungkan dengan sarana-sarana yang lain, apakah yang menggunakan sosialisasi kampanye eksternal dan internal. Bila promosi dalam eksternal, maka harus diketahui karateristik masyarakatnya terlebih dahulu.Misalnya, masyarakat yang senang tertentu, maka sosialisasi program sangat baik bila melalui sarana tersebut. Kondisi sedemikian sama dengan menciptakan keintiman dengan mengikuti kebiasaan masyarakat setempat. Bila ingin positioning bagus, maka pilihlah simbol terlebih dahulu dengan sosok, baru kemudian "ditembakan" pesan dimasukkan dalam hubungan di masyarakat terkepung dalam informasi iklan. Kemudian yang juga diperhatikan adalah bagaimana dengan kondisi dan sudah diketahui karateristik media massa tersebut. Dengan penggunaan aplikasi Amazing Blitar ini sebagai sarana yang sudah tepat dalam mempromosikan pariwisata di Kabupaten Blitar karena para wisatawan tinggal mengunduh aplikasi ini melalui google playstore.

\section{I - Integrating}

Integrating ini sangat tergantung pada bagaimana perencanaan dalam melakukan transfer pesan guna mengintegrasikan kesatuan program. Sering terjadi, program sosialisasi strategi tidak sesuai antara yang satu dengan yang lain, sedangkan dalam pola integrating ini adalah adanya upaya kegiatan mengkrucut kepada tujuan. Satu tujuan makro dalam strategi komunikasi pemasaran yang ada. Tujuannya hanya satu yaitu tidak terpecah-pecahnya pada peran dan misi masing-masing. Biasanya kalau ada sistem yang terintegrasi, yaitu terjadi adalah pesan yang diajukan tidak sampai dan diintepretasikan berbeda. Pesan atau informasi yang disampaikan di dalam aplikasi Amazing Blitar ini sudah sangat lengkap sehinga para wisatawan merasa puas dengan layanan aplikasi Amazing Blitra tersebut.

\section{T - Tools}

Pemilihan sarana yang sesuai dengan waktu serta beberapa tuntas keinginan yang dicapai perlu distrategikan dalam jangka waktu tertentu pada tools ini lebih difokuskan pada sarana yang cocok dengan situasi dan kondisi lapangan. Kemampuan karateristik dari media yang digunakan adalah inti dari analisis dalam penyusunan strategi dengan menggunakan sarana publikasi. Karena di masa pandemi Covid-19 dengan adanya aplikasi Amazing Blitar ini para wisatawan akan lebih mudah dalam mengakses termpat wisata di Kabupaten Blitar melalui aplikasi ini dan tidak perlu mendatangi langsung pusat informasi pariwisata di kantor pusat informasi pariwisata Kabupaten Blitar.

\section{Kesimpulan}

Adanya penggunaan strategi komunikasi pemasaran STOP SIT pada strategi komunikasi pemasaran dalam pengembangan pariwisata daerah Kabupaten Blitar pada penggunaan aplikasi Amazing Blitar yaitu Segmentation, Targeting, Objectives, Positioning, Sequence of Tools, Integrating, Tools. Pada strategi komunikasi pemasaran alam pengembangan pariwisata daerah Kabupaten Blitar pada penggunaan aplikasi Amazing Blitar terus dilakukan kajian untuk mengetahui kekuatan dan kelemahan aplikasi Amazing Blitar, mengidentifikasi semua peluang dan hambatan atau ancaman yang dihadapi. Program promosi atau pengembangan pemasaran dipersiapkan dengan mempertimbangkan berbagai aspek, dan menganalisa pasar yang dituju 


\section{Jurnal Komunikasi Nusantara}

\section{E-ISSN. 2685-7650}

Vol. 2 No. 2 (2020), pp 81-91

DOI: https://doi.org/10.33366/jkn.v2i2.54

yaitu para wisatawan baik dari dalam Kabupaten Blitar maupun luar Kabupaten Blitar. Adanya segmentasi pasar yang dilakukan diharapkan sering mengadakan event atau kegiatan budaya di tempat wisata sehingga lebih diminati para wisatawan. Agar tujuan strategi komunikasi pemasaran STOP SIT pada strategi komunikasi pemasaran dalam pengembangan pariwisata daerah Kabupaten Blitar pada penggunaan aplikasi Amazing Blitar tercapai sebaiknya juga melakukan pemantauan dan evaluasi yang sampai pada evaluasi terhadap pemunculan atau pemuatan pesan melalui media-media yang digunakan (message transmission), pengukuran pemahaman pesan oleh target konsumen atau pembeli, maupun pengukuran pengaruh atau efek pesan terhadap opini, persepsi dan perilaku konsumen.

\section{Daftar Pustaka}

Afrilia, A. M. (2018). Digital Marketing Sebagai Strategi Komunikasi Pemasaran "WAROENK ORA UMUM" dalam Meningkatkan Jumlah Konsumen. Jurnal Riset Komunikasi, 1(1), 147-157. https://doi.org/10.24329/jurkom.v1i1.21

Alifahmi, H. (2005). Strategi Komunikasi Pemasaran: Integrasi Iklan, Public Relations, dan Promosi. Jakarta: PT. Mizan Pustaka.

Aprilya, T. (2017). Strategi Komunikasi Pemasaran Nadyasfashop Melalui Instagram Dalam Meningkatkan Kepercayaan Customer Di Samarinda. EJournal Ilmu Komunikasi, 5(1), $13-23$.

Armstrong, G., \& Kotler, P. (2004). Dasar-Dasar Pemasaran Jilid 2 (Jilid 2). Jakarta: Indeks.

Asrori, M. (2016). Pengertian, Tujuan Dan Ruang Lingkup Strategi Pembelajaran. MADRASAH, 5(2), 163-188. https://doi.org/10.18860/jt.v6i2.3301

Chrismardani, Y. (2014). Komunikasi Pemasaran Terpadu: Implementasi untuk UMKM. NeoBis, 8(2), 176-189. https://doi.org/10.21107/NBS.V8I2.472

Delozier, M. W. (1976). The Marketing Communication Proses. Tokyo: Mc. Graw Hill Kagakusha, Ltd.

Kusniadji, S. (2016). Strategi Komunikasi Pemasaran dalam Kegiatan Pemasatan Produk Consumer Goods. In Jurnal Komunikasi. https://doi.org/10.24912/jk.v8i1.49

Lukitaningsih, A. (2013). Iklan yang Efektif sebagai Strategi Komunikasi Pemasaran. Jurnal Ekonomi Dan Kewirausahaan, 13(2), 116-129.

Miles, B. M., \& Huberman, M. (1992). Analisis Data Kualitatif. Jakarta: Universitas Indonesia Press.

Moleong, L. J. (2014). Metodologi Penelitian Kualitatif Edisi Revisi. Bandung: PT. Remaja Rosdakarya.

Nickels, W. G. (1984). Marketing Communication and Promotion (Third Edition). New York: John Wiley \& Sons. Inc.

Sarastuti, D. (2017). Strategi Komunikasi Pemasaran Online Produk Busana Muslim Queenova. Visi Komunikasi, 16(1), 71-90.

Sembiring, J. P. (2016). Strategi Komunikasi Pemasaran Objek Wisata Gundaling dan Pemandian Air Panas Semangat Gunung. Jurnal Simbolika, 2(1), 1-22.

Wijaya, I. S. (2015). Perencanaan Dan Strategi Komunikasi Dalam Kegiatan Pembangunan. Lentera, XVIII(1), 53-61. 